\begin{tabular}{l|l|l} 
Jurnal Eksplorasi Akuntansi &
\end{tabular} \mid $\begin{aligned} & \text { ISSN : 2656-3649 (Online) } \\
& \text { holtp://jea.ppj.unp.ac.id/index.php/jea/issue/view/29 }\end{aligned}$

\title{
Pengaruh Pertumbuhan Ekonomi, Pendapatan Asli Daerah (PAD), Jumlah Penduduk Dan Luas Wilayah Terhadap Belanja Modal Pemerintah Daerah (Studi Empiris Pada Pemerintah Daerah Kabupaten/Kota di Sumatera Barat Tahun 2016-2019)
}

\author{
Bintang Marseno ${ }^{1}$, Erly Mulyani² \\ ${ }^{1}$ Alumni Jurusan Akuntansi Fakultas Ekonomi Universitas Negeri Padang \\ ${ }^{2}$ Jurusan Akuntansi Fakultas Ekonomi Universitas Negeri Padang \\ *Korespondensi: bintangmarseno1@gmail.com
}

\begin{abstract}
This study aims to see the effect of Economic Growth, Local Own Revenue (PAD), Total Population, and Area of Regional Government on Capital Expenditures in Regency/City in West Sumatra Province. This type of research is quantitative research. The sample in this study is the report on the realization of the APBD in 19 regency/ cities in West Sumatra for the 20162019 fiscal year. The data analysis technique used is Multiple Linear Regression Analysis with the help of SPSS 24. Based on the Multiple Linear Regression Analysis with a significance level of 0.05, the results show that Local Own Revenue (PAD) and Regional Area have a significant effect on Capital Expenditures, where the significant level - are 0.000 and 0.000, respectively.
\end{abstract}

Keyword: Capital Expenditures, Economic Growth, Local Own Revenue, Population, Area of Regional, development financing

How to cite (APA $6^{\text {th }}$ style):

Marseno, B. \& Mulyani, E. (2020). Pengaruh Pertumbuhan Ekonomi, Pendapatan Asli Daerah (Pad), Jumlah Penduduk Dan Luas Wilayah Terhadap Belanja Modal Pemerintah Daerah (Studi Empiris Pada Pemerintah Daerah Kabupaten/Kota Di Sumatera Barat Tahun 2016-2019). Jurnal Eksplorasi Akuntansi, 2(4), Seri A. 3452-3467.

\section{PENDAHULUAN}

Sistem pertanggungjawaban dan pengelolaan keuangan daerah yang tercermin dalam Anggaran Pendapatan dan Belanja Daerah (APBD) merupakan bentuk otorisasi yang dilaksanakan oleh pemerintah, yaitu evaluasi kinerja masing-masing unit perangkat daerah. Undang-Undang Nomor 17 Tahun 2003 tentang Pasal 19 ayat 1 dan 2 Keuangan Negara menegaskan hal tersebut, yaitu tata cara berdasarkan prestasi kerja. Dengan membangun sistem anggaran yang dapat mengintegrasikan rencana kinerja dengan anggaran tahunan, akan memungkinkan untuk melihat keterkaitan antara dana yang tersedia dan hasil yang diharapkan.

Pada era setelah reformasi sekarang ini perhatian masyarakat tertuju terhadap kinerja keuangan pemerintah daerah dan juga pelayanan yang diberikan pemerintah daerah kepada masyarakat, selain itu pemerintah daerah juga dituntut untuk melakukan pengalokasian belanja modal secara tepat. Sejak diberlakukannya UU No. 22 tahun 1999 mengenai pemerintah daerah 
kemudian dilakukan revisi menjadi UU No. 32 tahun 2004 yang mengatur mengenai otonomi daerah. Anggaran Pendapatan dan Belanja Daerah (APBD) merupakan salah satu alat untuk meningkatkan pendapatan layanan publik dan kesejahteraan masyarakat berdasarkan tujuan otonomi daerah yang luas, benar, dan bertanggung jawab yang disepakati dengan pemerintah daerah dan DPRD sesuai dengan peraturan daerah. APBD juga harus mencerminkan pemenuhan kebutuhan masyarakat, dengan menitikberatkan pada potensi dan keragaman daerah (Abdul Halim dan Syam Kusufi, 2012).

Diharapkan dengan adanya anggaran guna mendapat aset tetap dan juga pendanaan untuk memelihara aset, maka pelaksanaan berbagai aktivitas dalam melayani kepentingan publik dapat lebih lancar dan terarah. Pertumbuhan ekonomi suatu daerah dapat diukur dengan tingkat Produk Domestik Regional Bruto (PDRB) yang dihasilkan. Menurut penelitian yang dilakukan Arsyad (2015:12) pertumbuhan ekonomi dapat dilihat dari peningkatan produktivitas dan pendapatan per kapita masing-masing penduduk.Dikarenakan kenaikan pendapatan per kapita menggambarkan adanya tambahan penghasilan serta adanya perbaikan terhadap kesejahteraan ekonomi rakyat. Dengan adanya peningkatan pertumbuhan ekonomi, seharusnya mampu mendorong untuk terwujudnya pembangunan daerah yang nantinya akan dapat meningkatkan alokasi belanja modal pemerintah daerah.

Pertumbuhan ekonomi merupakan salah satu pengukuran dari kemajuan suatu daerah. Dengan pertumbuhan ekonomi yang stabil dan baik, dapat meningkatkan kesejahteraan masyarakat, selain itu pelayanan publik juga dapat dijalankan secara maksimal tanpa adanya kendala. Untuk mewujudkan pertumbuhan ekonomi yang merata dan stabil perlu adanya kebijakan yang konkrit dari pemerintah daerah serta adanya perencanaan yang matang (Aryani, 2017). Berdasarkan PP No. 71 Tahun 2010, Pendapatan Asli Daerah merupakan sumber pendapatan yang diperoleh daerah dari pengelolaan kekayaan sumber daya ekonomi maupun potensi ekonomi yang dimiliki daerah yang dapat digunakan untuk pembangunan infrastruktur untuk peningkatan kesejahteraan dan kemajuan daerah. pengelolaan pendapatan asli daerah bergantung pada setiap kebijakan dari masing-masing daerah melalui peraturan yang dibuat oleh kepala daerah. Berdasarkan undang-undang nomor 32 tahun 2004, pendapatan asli daerah terdiri dari retribusi daerah, hasil pajak daerah, hasil pengelolaan sumber daya alam atau kekayaan daerah, serta pendapatan lain-lain PAD yang sah.

Jumlah penduduk dari setiap daerah kabupaten dan kota akan mempengaruhi peningkatan belanja daerah. Jumlah penduduk yang banyak dari sebuah daerah, menurut para ahli dalam perencanaan pembangunan dapat dikategorikan sebagai aset dasar untuk pembangunan sebuah daerah untuk dapat maju dan berkembang. Namun, hal tersebut dapat menimbulkan permasalahan baru yakni permasalahan pembiayaan serta beban dalam proses pembangunan. Pemerintah daerah dalam menentukan anggaran belanja modal, harus mempertimbangkan kebutuhan daerah terhadap fasilitas sarana dan prasarana yang akan dibagun, yang dapat berguna untuk memperlancar tugas pemerintah daerah, sehingga pemerintah daerah dapat memberikan pelayanan kepada masyarakat secara optimal(Asmuruf et al., 2015). Selain itu, dengan belanja modal yang memadai, pemerintah dapat memaksimalkan dalam pembangunan fasilitas publik yang dibutuhkan.

Luas wilayah merupakan kesatuan geografis dari suatu daerah beserta seluruh unsure yang terkait terhadap batas dan sistem yang berlaku yang ditentukan berdasarkan aspek administrastif serta aspek fungsional yang dimiliki (Kusnandar dan Siswantoro, 2016). Jika suatu daerah mempunyai wilayah yang cukup luas, maka akan menghabiskan biaya pembangunan yang tidak sedikit. Sehingga jika daerah tersebut ingin maju dan sejahtera, maka pemerintah daerah harus 
menyediakan anggaran yang banyak untuk dapat melakukan pembangunan.Untuk dapat mewujudkan pembangunan serta kemajuan daerah, maka pemerintah daerah harus mampu mengoptimalkan serta harrus mampu memanfaatkan penggunaan serta pengalokasian belanja modal nya (Putra, 2017).

Berdasarkan pemahaman diatas, motivasi yang melandasi penelitian ini adalah pengalokasian anggaran belanja modal yang semakin meningkat setiap tahunnya. Berbagai cara telah ditempuh oleh pemerintah daerah untuk meningkatkan pelayanan publik, salah satunya dengan menggunakan belanja modal untuk mencapai tujuan investasi (Solikin, 2010). Sehingga, peningkatan belanja modal diharapkan dapat meningkatkan kualitas pelayanan publik dan meningkatkan tingkat partisipasi (kontribusi) masyarakat dalam pembangunan.

Dimana, sarana dan prasarana di Sumatera Barat masih sangat rendah, ketergantungan pemerintah daerah yang tinggi pada bantuan pemerintah pusat dan kemampuan daerah untuk meningkatkan Pendapatan Asli Daerah (PAD) masih lemah, sehingga hal ini secara langsung akan mempengaruhi kemampuan pendanaan rutin dan anggaran pembangunan daerah (Kafi, 2011). Berdasarkan uraian yang telah disampaikan diatas maka peneliti tertarik meneliti tentang "'Pengaruh Pertumbuhan Ekonomi, Pendapatan Asli Daerah (PAD), Jumlah Penduduk dan Luas Wilayah Terhadap Belanja Modal Pemerintah Daerah ( Studi Empiris Pada Pemerintah Daerah Kabupaten/Kota di Sumatera Barat Tahun 2016-2019).

\section{REVIU LITEARATUR \\ Teori Keagenan}

Dalam pemerintahan pihak yang berperan sebagai principal atau pemberi wewenang adalah pemerintah pusat, sedangkan yang berperan sebagai agen atau yang melaksanakan tugas/wewenang adalah pemerintah daerah. Pemerintah pusat akan mendelegasikan wewenang kepada pemerintah daerah untuk mengelola pemerintahannya sendiri tetapi tetap pemerintah pusat tidak sepenuhnya lepas tangan. Salah satu bukti campur tangan pemerintah pusat adalah dengan memberikan bantuan berupa dana perimbangan yang bertujuan untuk membantu mendanai kebutuhan daerah dengan harapan daerah bisa mandiri dalam menghasilkan pedapatan asli daerahnya sendiri pada masa yang akan datang.

\section{Stakeholder Theory}

Variabel Pertumbuhan Ekonomi, Pendapatan Asli Daerah (PAD), Jumlah Penduduk dan Luas Wilayah memiliki hubungan dengan teori stakeholder dimana pemerintah daerah mengelola Pertumbuhan Ekonomi, Pendapatan Asli Daerah yang juga bersumber dari masyarakat dan dana perimbangan yang didapatkan dari transfer pemerintah pusat yang akan digunakan untuk mengembangkan potensi daerah serta mendorong pertumbuhan ekonomi untuk meningkatkan kesejahteraan rakyat sebagai stakeholder.

\section{Belanja Modal}

Dalam Peraturan Menteri Keuangan Nomor 91 / PMK.06 / 2007 tentang Standar Bagan Akun, disebutkan belanja modal sebagai belanja anggaran untuk perolehan atau penambahan aset tetap dan aset lain yang memberikan manfaat lebih dari satu periode akuntansi serta melebihi batas kapitalisasi minimum untuk aset tetap atau Aset lain ditentukan oleh pemerintah dimana aset tersebut digunakan dalam operasi sehari-hari dari unit kerja yang tidak dapat dijual.

Berdasarkan Keputusan Menteri dalam Negeri nomor 29 Tahun 2002, belanja modal dibagi menjadi: 
1) Belanja Publik, yaitu belanja yang manfaatnya dapat dinikmati secara langsung oleh masyarakat umum.

2) Belanja Aparatur, yaitu belanja yang manfaatnya tidak secara langsung dinikmati oleh masyarakat, tetapi dirasakan secara langsung oleh aparatur.

Belanja Modal dapat diakategorikan dalam 5 (lima) kategori utama (Syaiful, 2006):

1. Belanja modal tanah mengacu pada penyelesaian pembebasan/ pembelian/ pelepasan, pengalihan nama dan sewa tanah, pengosongan, penimbunan, perataan, pembukaan lahan, pembuatan sertifikat, dan pengeluaran/ biaya lain yang terkait dengan perolehan hak atas tanah sampai tanah dalam kondisi baik.

2. Belanja peralatan dan mesin mengacu pada biaya/ pengeluaran yang digunakan untuk membeli/ menambah/ mengganti serta untuk meningkatkan efisiensi peralatan dan mesin serta menambah sumber daya kantor yang memberikan manfaat selama lebih dari 12 (dua belas) bulan, untuk waktu memulai peralatan dan mesin.

3. Belanja Modal Bangunan dan Gedung adalah pengeluaran/ biaya yang digunakan untuk pengadaan/ penambahan/ penggantian, termasuk biaya perencanaan, pengawasan dan pengelolaan gedung dan pembangunan gedung yang menambah kapasitas hingga gedung dan gedung tersebut dalam keadaan siap pakai.

4. Belanja modal jalan, irigasi, dan jaringan adalah pengeluaran/ biaya yang digunakan untuk membeli/ menambah/ mengganti/ meningkatkan konstruksi/ produksi dan pemeliharaan serta meliputi pengeluaran untuk perencanaan, pengawasan, dan pengelolaan jalan dan jaringan irigasi yang meningkatkan kapasitas jalan dan jaringan irigasi sampai jalan irigasi dan jaringan tersebut dalam kondisi tersedia dan siap pakai.

5. Belanja modal fisik lainnya adalah pengeluaran/ biaya yang digunakan untuk membeli/ menambah/ mengganti konstruksi/ produksi serta pemeliharaan fisik lainnya yang tidak diklasifikasikan dalam kriteria belanja modal untuk tanah, peralatan dan mesin, gedung dan gedung serta jalan dan jaringan irigasi. Termasuk dalam biaya biaya ini adalah biaya investasi yang berkaitan dengan perjanjian sewa-beli, pembelian barang-barang kesenian, arkeologi dan museum, ternak dan tumbuhan, buku dan jurnal ilmiah.

\section{Pertumbuhan Ekonomi}

Pertumbuhan ekonomi didefinisikan sebagai ukuran kuantitatif yang digunakan untuk menggambarkan perkembangan ekonomi pada tahun tertentu dibandingkan tahun sebelumnya. Pertumbuhan ekonomi didefinisikan sebagai pertumbuhan produk domestik bruto (PDB), terlepas dari apakah pertumbuhan tersebut lebih besar atau lebih kecil dari tingkat pertumbuhan penduduk, dan apakah struktur ekonomi telah berubah atau apakah sistem kelembagaan telah membaik.

Pertumbuhan ekonomi merupakan peningkatan pendapatan nasional yang signifikan dalam kurun waktu tertentu (peningkatan pendapatan per kapita). Menurut Mankiw yang dikutip oleh Menik Fitriani Safari, PDB sering dianggap sebagai ukuran terbaik dari kinerja perekonomian. Tujuan PDB adalah meringkas aktivitas ekonomi dalam suatu nilai uang tertentu selama periode waktu tertentu. Ada dua cara untuk memeriksa ukuran PDB: Yang pertama adalah dengan menganggap PDB sebagai total pendapatan semua orang dalam perekonomian. Cara lain untuk mengamati PDB adalah dengan menggunakan total pengeluaran untuk output produk dan jasa ekonomi. 
Ada banyak faktor yang mempengaruhi perekonomian di era modern. Para ekonom percaya bahwa faktor produksi adalah kekuatan utama yang mempengaruhi pertumbuhan. Beberapa faktor produksi antara lain:

1. Sumber Daya Alam merupakan faktor utama yang mempengaruhi pertumbuhan ekonomi.

2. Akumulasi Modal atau pembentukan modal adalah peningkatan stok modal dalam jangka waktu tertentu.

3. Organisasi bersifat melengkapi (komplemen) modal, buruh, dan membantu meningkatkan produktivitasnya.

4. Kemajuan Teknologi merupakan yang paling penting dalam pertumbuhan ekonomi yaitu untuk meningkatkan produktivitas, modal dan faktor produksi lainnya.

5. Pembagian kerja dan skala produksi, spesialisasi dan pembagian kerja dapat meningkatkan produktivitas. Keduanya telah menghasilkan ekonomi produksi skala besar, yang pada gilirannya mendorong perkembangan industri.

\section{Pendapatan Asli Daerah (PAD)}

Menurut UU No. 28 Tahun 2009 tentang Pendapatan Pajak Daerah dan Retribusi Daerah, PAD adalah sumber keuangan daerah yang digali dari Daerah yang terdiri dari hasil pajak daerah, retribusi daerah, hasil pengelolaan kekayaan daerah yang dipisahkan, dan pendapatan asli daerah lainnya yang sah. Sementara itu, menurut Lazio (2012: 1) PAD adalah semua pendapatan keuangan suatu daerah, dimana pendapatan tersebut berasal dari potensi yang ada di daerah tersebut misalnya pajak daerah, retribusi daerah dan lain-lain, dan pendapatan keuangan diatur dengan peraturan daerah. Sedangkan menurut Sugiyono (2014: 4) PAD merupakan pendapatan daerah yang bersumber dari pengelolaan kekayaan daerah yang dipisahkan. Adapun sumbersumber PAD sebagaimana yang diataur dalam Undang-Undang Nomor 32 Tahun 2004 Pasal 157, yaitu:

\section{Pajak Daerah}

Hasil pajak daerah merupakan pungutan daerah sesuai peraturan yang ditetapkan oleh daerah untuk membiayai rumah tangganya sebagai badan hukum publik. Pajak daerah adalah pungutan yang dikenakan oleh pemerintah daerah yang dananya digunakan untuk pengeluaran umum yang tidak segera diberikan imbalannya selama pelaksanaannya dapat dilaksanakan. Pemungutan dan pengelolaan pajak daerah merupakan kewenangan yang dimiliki dan dilaksanakan oleh biro pajak daerah. Pajak daerah yang baik merupakan perpajakan yang akan mendukung pelimpahan kewenangan kepada daerah dalam rangka desentralisasi pembiayaan. Untuk itu, pemerintah daerah dalam pemungutan pajak harus tetap menempatkannya sesuai dengan fungsinya.

\section{Retribusi Daerah}

Hasil Retribusi daerah adalah pungutan yang telah secara hukum menjadi pungutan daerah sebagai pembayaran atas pemakaian atau untuk memperoleh pekerjaan, usaha atau milik pemerintah daerah yang bersangkutan. Retribusi daerah memiliki ciri khas yaitu pelaksanaannya ekonomis, ada imbalan langsung walaupun harus memenuhi persyaratan formal dan materil, namun ada alternatif suka atau tidak suka yaitu pungutan yang anggarannya tidak menonjol, dalam hal-hal tertentu. Retribusi daerah merupakan pengembalian biaya yang dikeluarkan pemerintah untuk memenuhi kebutuhan masyarakat. 


\section{Hasil Pengelolaan Kekayaan Daerah Yang Dipisahkan}

Hasil Pengelolaan Kekayaan Daerah yang dipisahkan adalah penerimaan daerah dari laba bersih perusahaan daerah berupa dana pembangunan daerah dan sebagian anggaran belanja daerah yang disetorkan ke kas daerah, keduanya merupakan perusahaan daerah yang dipisahkan, sesuai motif pendirian dan pengelolaan, maka sifat perusahaan daerah adalah unit produksi yang meningkatkan pendapatan daerah, memberikan pelayanan, memberikan kemanfaatan umum, dan mampu menggerakkan perekonomian daerah.

\section{Pendapatan Asli Daerah Lain-lain Yang Sah}

Pendapatan Asli Daerah Lainnya adalah penerimaan yang tidak termasuk dalam jenis pajak daerah, retribusi daerah, penerimaan dari instansi pemerintah. Pendapatan daerah lain yang sah dirancang untuk mendukung, memperluas atau memperkuat kebijakan daerah di bidang tertentu.

\section{Jumlah Penduduk}

Penduduk Indonesia menurut Badan Pusat Statistik adalah semua orang yang telah tinggal di wilayah teritorial Indonesia selama 6 bulan atau lebih dan atau yang telah tinggal kurang dari 6 bulan tetapi mempunyai tujuan menetap. Penduduk juga berperan penting dalam meningkatkan belanja daerah. Artinya, jumlah penduduk di suatu provinsi sangat berpengaruh dalam meningkatkan belanja daerah. Besar kecilnya jumlah penduduk akan dihadapkan pada seberapa cepat kemampuan menambah jumlah sarana pemuas kebutuhan serta sarana dan prasarana untuk memenuhi kebutuhan tersebut. Dalam pengumpulan data penduduk bisa dilakukan dengan tiga cara/metode yakni:

a. Sensus, yaitu pendataan penduduk secara menyeluruh.

b. Survei, yaitu pendataan penduduk secara sampel.

c. Sistem Registrasi Penduduk, yaitu pendataan penduduk berdasarkan catatan resmi pada instansi-instansi yang berwenang misalnya kelurahan. Sensus penduduk di Indonesia hanya dilakukan 10 tahun sekali, sehingga jumlah penduduk per tahun didapat berdasarkan perhitungan proyeksi penduduk. Tersedianya data kependudukan yang akurat sangat membantu dalam tercapainya perencanaan pembangunan nasional.

\section{Luas Wilayah}

Wilayah adalah sebuah daerah yang dikuasai atau menjadi wilayah kedaulatan. Dahulu suatu kawasan sering kali dikelilingi oleh kondisi fisik yang alami seperti sungai, pegunungan, atau laut. Wilayah pemerintahan merupakan penjumlahan dari luas wilayah suatu pemerintahan, baik itu kabupaten, kota, maupun wilayah geografis (Afkarina, 2017). Luas wilayah menurut UndangUndang Nomor 33 Tahun 2004 merupakan variabel yang mencerminkan kebutuhan penyediaan sarana dan prasarana per satuan wilayah. Artinya semakin besar luas suatu wilayah pemerintahan maka semakin banyak pula sarana dan prasarana yang harus disediakan oleh pemerintah daerah agar dapat memberikan pelayanan publik yang efektif. Terkait dengan pemekaran wilayah, luas wilayah kemungkinan besar terkait erat dengan penganggaran belanja modal.

\section{Penelitian Terdahulu}

Penelitian ini mengacu pada beberapa penelitian-penelitian terdahulu sebagai bahan referensi. Diantaranya, Nurin Hidayati (2016), Kusnandar, Dodik Siswanto (2012), Choilil Inayah (2013), dan Ni Putu Dwi Eka Rini Sugiarthi, Ni Luh Supadmi (2014). 


\section{METODE PENELITIAN}

\section{Jenis Penelitian}

Penelitian ini menggunkan pendekatan penelitian kuantitatif. Pendekatan kuantitatif bertujuan untuk untuk mendapatkan penjelasan dari sebuah teori dan hukum-hukum realitas. Penelitian Kuantitatif seringkali di pakai untuk melihat bukti dan menampik suatu teori, kemudian di bahas dan diambil kesimpulan.

\section{Lokasi Penelitian}

Pemerintah Provinsi Sumatera Barat dipilih dalam penelitian ini karena Sumatera Barat merupakan daerah yang membutuhkan pembiayaan dalam pembangunan infrastruktur publik.

\section{Sumber Data}

Sumber data yang digunakan yaitu data sekunder. Data sekunder yaitu berupa laporan realisasi APBD Kabupaten/Kota Provinsi Sumatera Barat yang diakses melalui situs resmi pemerintah www.djpk.depkeu.go.id dan data jumlah penduduk yang diperoleh dari Badan Pusat Statistik Provinsi Sumatera Barat.

\section{Teknik Pengumpulan data}

Teknik pengumpulan data dalam penulisan proposal penelitian ini, digunakan dengan cara penelitian studi kepustakaan dan penelitian lapangan.

\section{Teknik Analisis data}

Analisis data kuantitatif yang digunakan adalah analisis regresi linier berganda untuk mengetahui ada tidaknya pengaruh dari variabel bebas terhadap variabel terikat. variabel bebas (independen variable) dalam penelitian ini adalah Pertumbuhan Ekonomi (X1), Pendapatan Asli Daerah (PAD) (X2), Jumlah Penduduk (X3), Luas Wilayah (X4) terhadap variabel terikat (dependen variable) yaitu Belanja Modal Pemerintah (Y). Dan persamaan regresinya dapat dirumuskan sebagai berikut:

$$
\mathrm{Y}=\mathrm{a}+\mathrm{b}_{1} \mathrm{X}_{1}+\mathrm{b}_{2} \mathrm{X}_{2}+\mathrm{b}_{3} \mathrm{X}_{3}+\mathrm{b}_{4} \mathrm{X}_{4}+\mathrm{e}
$$

Keterangan:

Y : Belanja Modal Pemerintah

a : Konstanta

$\mathrm{X}_{1} \quad$ : Pertumbuhan Ekonomi

$\mathrm{X}_{2} \quad$ : Pendapatan Asli Daerah

$\mathrm{X}_{3} \quad$ : Jumlah Penduduk

$\mathrm{X}_{4} \quad$ : Luas Wilayah

$\mathrm{b}_{1.2 .3} \quad$ : Koefisien regresi

e : Variabel yang tidak diteliti

\section{Keabsahan Data}

Untuk menguji keabsahan data pada metode penelitian kuantitatif dapat dilakukan, uji (1) Asumsi Klasik diantaranya dengan uji normalitas, Uji Multikolonieritas, Uji Heteroskendastisitas, (2) Uji hipotesis, diantaranya Uji t, Uji F dan Koefisien Determinasi $\left(\mathrm{R}^{2}\right)$. 


\section{HASIL DAN PEMBAHASAN \\ Statistik Deskriptif}

Data penelitian yang menjadi variabel dependen (Y) yaitu belanja modal sedangkan yang menjadi variabel independen adalah pertumbuhan ekonomi (X1), pendapatan asli daerah (X2), jumlah penduduk (X3), dan Luas Wilayah (X4).

\section{Tabel 1}

Hasil Uji Statistik Deskriptif Variabel

\begin{tabular}{|c|c|c|c|c|c|c|}
\hline & & $\begin{array}{l}\text { Pertumbuhan } \\
\text { Ekonomi }\end{array}$ & $\begin{array}{c}\text { Pendapatan Asli } \\
\text { Daerah (PAD) }\end{array}$ & $\begin{array}{c}\text { Jumlah } \\
\text { Penduduk }\end{array}$ & Luas Wilayah & $\begin{array}{c}\text { Belanja Modal } \\
\text { Pemerintah }\end{array}$ \\
\hline \multirow[t]{2}{*}{$\mathrm{N}$} & Valid & 76 & 76 & 76 & 76 & 76 \\
\hline & Missing & 0 & 0 & 0 & 0 & 0 \\
\hline \multicolumn{2}{|c|}{ Mean } & 536.12 & 108335704200.00 & 273434.21 & 2211.20 & 217164432400.00 \\
\hline \multicolumn{2}{|c|}{ Median } & 533.00 & 86306634620.00 & 234643.00 & 1804.30 & 205567752500.00 \\
\hline \multicolumn{2}{|c|}{ Std. Deviation } & 51.167 & 98505569350.000 & 213720.684 & 1943.969 & 80113626660.000 \\
\hline \multicolumn{2}{|c|}{ Minimum } & 251 & 29680784160 & 51712 & 23 & 77527748800 \\
\hline \multicolumn{2}{|c|}{ Maximum } & 623 & 548653179300 & 950871 & 6011 & 491009055000 \\
\hline
\end{tabular}

\section{Model Regresi Linear berganda}

Dari hasil pengolahan menggunakan SPSS 24 diatas, maka diperoleh persamaan regresi data panel sebagai berikut :

\section{$\mathrm{Y}=$ 148.065.940.600,000 $+-64.998 .711,410 \mathrm{PE}+0,441 \mathrm{PAD}+\mathbf{8 5 . 7 1 6 , 3 8 3} \mathrm{JP}+$ 14.816.019,050 LW + e}

Dari persamaan di atas dapat dapat dijelaskan sebagai berikut:

a) Konstanta sebesar 148.065.940.600,000 menunjukkan bahwa nilai variabel independen dan interaksi variabel independen dianggap nol maka nilai Belanja Modal Pemerintah sebesar 148.065.940.600,000.

b) Koefisien variabel pertumbuhan ekonomi sebesar $-64.998 .711,410$, artinya apabila terjadi kenaikan nilai pertumbuhan ekonomi sebesar 1 level maka akan menurunkan Belanja Modal Pemerintah sebesar -64.998.711,410.

c) Koefisien variabel pendapatan asli daerah sebesar 0,441, artinya apabila terjadi kenaikan nilai pendapatan asli daerah sebesar sebesar 1 level akan menaikan belanja modal pemerintah sebesar 0,441 .

d) Koefisien variabel jumlah penduduk sebesar 85.716,383, artinya apabila terjadi kenaikan jumlah penduduk sebesar 1 level akan menaikan belanja modal pemerintah sebesar 85.716,383.

e) Koefisien variable luas wilayah sebesar 14.816.019,050, artinya apabila terjadi kenaikan luas wilayah sebesar 1 level akan menaikan belanja modal pemerintah sebesar 14.816.019,050.

\section{Uji Asusmsi Klasik}

Uji Normalitas

Hasil penelitian menunjukkan bahwa nilai Asym.Sig (2-tailed) untuk unstandardized residual sebesar 0,200, dapat disimpulkan bahwa nilai Asym.Sig (2-tailed) dalam penelitian ini nilainya lebih besar dari tingkat signifikan yang digunakan pada penelitian yaitu $(\alpha=0,05)$. 
Dengan demikian dapat disimpulkan bahwa semua variabel penelitian berdistribusi normal, dengan demikian analisis regresi linear berganda dapat dilaksanakan karena data telah berdistribusi normal.

\section{Uji Multikolinearitas}

Berdasarkan hasil uji multikolonieritas menunjukkan bahwa nilai tolerance semua variable penelitian adalah $>0,1$ yang berarti bahwa tidak terjadi korelasi antar variabel independen. Hasil yang sama dilihat dari nilai VIF semua variabel menunjukkan angka dibawah 10. Jadi dapat disimpulkan bahwa model regresi terbebas dari multikolonieritas antar variabel.

\section{Uji Heteroskedastisitas}

Hasil pengujian menunjukkan penyebaran data tidak teratur, hal tersebut terlihat pada plot yang menyebar atau terpencar dan tidak membentuk pola tertentu, maka dapat disimpulkan tidak ada terjadi heterokedastisitas.

\section{Uji Model}

\section{Koefisiensi Determinasi $\left(\mathbf{R}^{2}\right)$}

Berdasarkan hasi analisis determinan diperoleh nilai R Square sebesar 0,656 atau (65,6\%). Hal ini menunjukkan bahwa persentase hubungan pengaruh variabel independen seraca bersamasama (simultan) terhadap variabel dependen sebesar $65,6, \%$, sisanya $34,4 \%$ dipengaruhi atau dijelaskan oleh variabel lain yang tidak termasuk model penelitian ini.

\section{Uji Hipotesa}

\section{Uji t}

Dari ketiga variabel independen yang dimasukkan kedalam model regresi ditemukan hasil sebagai berikut:

a) Hasil uji t Pertumbuhan Ekonomi

Hasil perhitungan variabel pertumbuhan ekonomi secara statistik menunjukkan hasil yang tidak signifikan pada nilai lebih besar dari $\alpha(0,626<0,05)$. Sedangkan nilai t hitung $\mathrm{X} 1=-0,490$ dan $\mathrm{t}$ tabel sebesar 1.993 sehingga $t$ hitung $<\mathrm{t}$ tabel $(-0,490<1.993)$. Maka $\mathrm{H} 1$ ditolak sehingga dapat disimpulkan bahwa variable pertumbuhan ekonomi berpengaruh negative dan tidak signifikan terhadap belanja modal Pemerintah pada Pemerintah Daerah Kabupaten/Kota di Sumatera Barat Tahun 2016-2019)

b) Hasil uji t Pendapatan Asli Daerah (PAD)

Hasil perhitungan variabel pendapatan asli daerah (PAD) secara statistik menunjukkan hasil yang signifikan pada nilai lebih kecil dari $\alpha(0,000<0,05)$. Sedangkan nilai t hitung X2 $=3.724$ dan $t$ tabel sebesar 1.993 sehingga $t$ hitung $>t$ tabel $(3.724>1.993)$. Maka $\mathrm{H} 2$ diterima sehingga dapat disimpulkan bahwa variable pendapatan asli daerah (PAD) berpengaruh positif terhadap belanja modal Pemerintah pada Pemerintah Daerah Kabupaten/Kota di Sumatera Barat Tahun 2016-2019).

c) Hasil uji t Jumlah Penduduk

Hasil perhitungan variabel jumlah penduduk secara statistik menunjukkan hasil yang tidak signifikan pada nilai lebih besar dari $\alpha(0,114<0,05)$. Sedangkan nilai $t$ hitung $\mathrm{X} 3=-0,490$ dan $\mathrm{t}$ 
tabel sebesar 1.993 sehingga t hitung $<\mathrm{t}$ tabel $(1.598<1.993)$. Maka H3 ditolak sehingga dapat disimpulkan bahwa variable jumlah penduduk tidak berpengaruh terhadap belanja modal Pemerintah pada Pemerintah Daerah Kabupaten/Kota di Sumatera Barat Tahun 2016-2019.

d) Hasil uji t Luas Wilayah

Hasil perhitungan variabel luas wilayah secara statistik menunjukkan hasil yang signifikan pada nilai lebih kecil dari $\alpha(0,000<0,05)$. Sedangkan nilai $t$ hitung X4 $=4.357$ dan $t$ tabel sebesar 1.993 sehingga $t$ hitung $>t$ tabel $(4.357>1.993)$. Maka $\mathrm{H} 4$ diterima sehingga dapat disimpulkan bahwa variable luas wilayah berpengaruh positif terhadap belanja modal Pemerintah pada Pemerintah Daerah Kabupaten/Kota di Sumatera Barat Tahun 2016-2019).

\section{Uji F}

Berdasarkan tabel diperoleh nilai $\mathrm{F}$ hitung sebesar 36.793 dengan signifikan 0,000 nilainya lebih kecil dari tingkat signifikan $\propto 5 \%(0,05)$, atau dilihat dari $\mathrm{F}$ hitung lebih besar pada $\mathrm{F}$ tabel $36.793>2,50$ Artinya bahwa pertumbuhan ekonomi, pendapatan asli daerah (PAD), jumlah penduduk dan luas wilayah bersama-sama berpengaruh positif dan signifikan terhadap belanja modal Pemerintah pada Pemerintah Daerah Kabupaten/Kota di Sumatera Barat Tahun 20162019)

\section{PEMBAHASAN}

\section{Pengaruh Pertumbuhan Ekonomi terhadap Belanja Modal Pemerintah Daerah}

Berdasarkan analisis statistik dalam penelitian ini ditemukan bahwa $\mathrm{H} 1$ ditolak dan dapat disimpulkan bahwa pertumbuhan ekonomi tidak berpengaruh terhadap belanja modal pemerintah daerah. Hal ini dapat dilihat dari nilai signifikansi sebesar 0,626 berarti tingkat signifikansinya diatas 0,05 dan nilai $\mathrm{t}_{\text {hitung }}<\mathrm{t}_{\text {tabel, }}$ yaitu $-0,490<1.993$ maka H1 ditolak.

Penelitian ini sejalan dengan penelitian yang dilakukan oleh Sularso dan Restianto (2018) bahwa belanja modal tidak berpengaruh terhadap pertumbuhan ekonomi dengan alasan bahwa dalam praktiknya usulan anggaran yang diajukan oleh eksekutif cenderung mengutamakan kepentingan eksekutif, dimana eksekutif menyampaikan anggaran baik secara finansial maupun anggaran. istilah non-keuangan untuk memenuhi kepentingan pribadi. Hasil ini juga sejalan dengan penelitian yang dilakukan oleh (Darwanto, 2017) yang menyatakan bahwa pertumbuhan ekonomi tidak diikuti oleh anggaran belanja modal yang signifikan. Hal ini disebabkan adanya penurunan data anggaran belanja modal, namun di sisi lain pertumbuhan ekonomi justru mengalami peningkatan.

Untuk menambah aset tetap, Pemerintah Daerah menganggarkan dana dalam bentuk anggaran belanja modal dalam APBD. Anggaran belanja modal ini berdasarkan kebutuhan daerah akan sarana dan prasarana, yaitu untuk kelancaran pelaksanaan tugas pemerintahan maupun untuk sarana umum. Untuk meningkatkan kualitas pelayanan publik, pemerintah daerah harus mengubah komposisi belanjanya. Selama ini cenderung belanja daerah lebih banyak digunakan untuk belanja rutin yang tidak produktif.

Pelaksanaan belanja modal sangat penting dilaksanakan dalam rangka peningkatan pembangunan daerah dan pemenuhan pelayanan publik yang baik. Peningkatan belanja modal oleh pemerintah daerah menjadi salah satu faktor peningkatan kepercayaan masyarakat terhadap pemerintah daerah. Peningkatan belanja modal dalam bentuk belanja gedung, irigasi, jalan, dan infrastruktur dapat meningkatkan kualitas pelayanan publik. Pasalnya, belanja modal dapat memberikan manfaat langsung kepada masyarakat dibandingkan belanja rutin. Oleh karena itu, 
semakin kecil nilai belanja modal dan belanja barang dan jasa, maka seharusnya semakin buruk dampaknya terhadap pertumbuhan ekonomi. (DJPK, 2015).

Penelitian ini sejalan dengan penelitian yang dilakukan oleh Maolana (2012) yang menunjukkan bahwa belanja modal tidak berpengaruh terhadap pertumbuhan ekonomi daerah, hal ini dikarenakan proporsi belanja modal pemerintah daerah yang tidak terlalu besar, dan alokasi belanja modal pada jalan dan jaringan irigasi hanya 46\% $69 \%$, sisanya digunakan untuk belanja modal yang berkaitan dengan urusan pemerintahan, seperti peralatan dan mesin, serta gedung dan gedung.

Oates (2016) memiliki perbedaan penelitian, yang berpengaruh signifikan terhadap pertumbuhan ekonomi suatu daerah yang akan berdampak pada penciptaan sektor publik di daerah tersebut. Secara umum pertumbuhan ekonomi dapat diartikan sebagai pembangunan yang menyebabkan peningkatan barang dan jasa produksi masyarakat dan peningkatan kesejahteraan masyarakat.

\section{Pengaruh Pendapatan Asli Daerah (PAD) terhadap Belanja Modal Pemerintah Daerah}

Berdasarkan analisis statistik dalam penelitian ini ditemukan bahwa $\mathrm{H} 2$ diterima dan dapat disimpulkan bahwa pendapatan asli daerah berpengaruh terhadap belanja modal pemerintah daerah. Hal ini dapat dilihat dari nilai signifikansi sebesar 0,000 berarti tingkat signifikansinya diatas 0,05 dan nilai $\mathrm{t}_{\text {hitung }}<\mathrm{t}_{\text {tabel, }}$ yaitu $3.724>1.993$ maka $\mathrm{H} 2$ diterima.

Hasil Analisis Regresi Linier Berganda untuk menguji bagaimana pengaruh PAD terhadap Belanja Modal menunjukkan bahwa PAD berpengaruh positif terhadap Belanja Modal pada Kabupaten/Kota di Sumatera Barat. PAD bertujuan untuk memberdayakan pemerintah daerah dalam menyediakan dana bagi penyelenggaraan otonomi daerah berdasarkan kinerja desentralisasi daerah. Dilihat dari nilai PAD yang terealisasi tahun 2016-2019, realisasi PAD di masing-masing kabupaten/ kota mengalami peningkatan. Begitu pula dalam realisasi belanja modal, belanja modal di hampir seluruh kabupaten/ kota di Sumatera Barat selalu mengalami peningkatan. PAD merupakan pendapatan daerah dan dapat digunakan sebagai sumber belanja daerah, salah satunya adalah belanja modal yang dilakukan oleh pemerintah daerah dalam menjalankan pemerintahan.

PAD berpengaruh positif terhadap Belanja Modal dapat disimpulkan bahwa semakin bertambah nilai PAD pada Kabupaten/Kota di Sumatera Barat maka semakin bertambah pula nilai realisasi Belanja Modal pemerintah Kabupaten/Kota di Sumatera Barat tersebut. Dengan PAD yang tinggi, pemerintah dapat mengalokasikan Belanja Modal semaksimal mungkin. Namun apabila PAD rendah, pemerintah akan sulit melaksanakan Belanja Modal yang maksimal.

Hasil ini sejalan dengan penelitian sebelumnya yang dilakukan oleh Aziz dkk. Pada tahun 2015 tentang dampak pajak daerah (pajak dari sumber daerah) terhadap belanja daerah; Blackley, 2016; yang menyatakan bahwa "penerimaan daerah (terutama pajak ) Akan mempengaruhi belanja pemerintah daerah, dikenal dengan namatax-spend hypothesis. Hal ini juga sesuai dengan hasil penelitian terdahulu yang dilakukan oleh Abdullah dan Halim (2018) bahwa "PAD berpengaruh positif terhadap belanja pemerintah pada kabupaten/kota di Jawa dan Bali". Hal ini juga sejalan dengan penelitian yang menunjukkan bahwa "PAD berpengaruh signifikan terhadap belanja modal di pemerintahan Sumatera Barat, dimana penerimaan daerah menunjukkan kapasitas daerah yang terus meningkat dan upaya peningkatan penerimaan daerah dari jalur penerimaan PAD semakin meningkat. dilakukan dengan benar. Sedangkan belanja modal menunjukkan bahwa semakin besar pendapatan daerah tumbuh maka belanja modal pemerintah akan semakin meningkat. 


\section{Pengaruh Jumlah Penduduk terhadap Belanja Modal Pemerintah Daerah}

Berdasarkan analisis statistik dalam penelitian ini ditemukan bahwa H3 ditolak dan dapat disimpulkan bahwa jumlah penduduk tidak berpengaruh terhadap belanja modal pemerintah daerah. Hal ini dapat dilihat dari nilai signifikansi sebesar 0,114 berarti tingkat signifikansinya diatas 0,05 dan nilai $\mathrm{t}$ hitung $<\mathrm{t}$ tabel, yaitu $1.598<1.993$ maka $\mathrm{H} 3$ ditolak sehingga dapat disimpulkan bahwa variable jumlah penduduk tidak berpengaruh terhadap belanja modal Pemerintah pada Pemerintah Daerah Kabupaten/Kota di Sumatera Barat Tahun 2016-2019.

Berdasarkan hasil pengujian yang menyatakan bahwa jumlah penduduk tidak berpengaruh terhadap belanja modal, hasil tersebut dapat diartikan bahwa jumlah penduduk tidak berpengaruh terhadap belanja modal. Hal tersebut kemungkinan karena infrastruktur dan infrastruktur pembangunan yang ada selama lima tahun terakhir masih memadai dan memadai sehingga pemerintah daerah khususnya Sumatera Barat tidak mengeluarkan anggaran untuk penambahan infrastruktur atau pembangunan sehingga jumlah penduduk tidak mempengaruhi belanja modal.

Hasil penelitian ini sejalan dengan penelitian Devita et.al (2015) yang meneliti wilayah Jambi dan Herlina (2013) yang meneliti wilayah Kabupaten Berau, Kalimantan bahwa ukuran populasi tidak berpengaruh signifikan terhadap modal. pengeluaran. Namun penelitian ini tidak sesuai dengan penelitian yang dilakukan oleh Budi (2013) di Jawa dan Widiagma (2013) di wilayah Jawa Timur yang membuktikan bahwa jumlah penduduk berpengaruh positif signifikan terhadap belanja modal.

\section{Pengaruh Luas Wilayah terhadap Belanja Modal Pemerintah Daerah}

Berdasarkan analisis statistik dalam penelitian ini ditemukan bahwa $\mathrm{H} 4$ diterima dan dapat disimpulkan bahwa luas wilayah berpengaruh terhadap belanja modal pemerintah daerah. Hal ini dapat dilihat dari nilai signifikansi sebesar 0,000 berarti tingkat signifikansinya diatas 0,05 dan nilai $\mathrm{t}_{\text {hitung }}<\mathrm{t}$ tabel, yaitu $4.357>1.993$ maka $\mathrm{H} 4$ diterima. Berdasarkan hasil penelitian yang diperoleh dari penelitian ini, menunjukkan bahwa Luas Wilayah Daerah berpengaruh signifikan positif terhadap Belanja Modal. Hal tersebut ditunjukkan dengan tingkat signifikansi variabel Luas Wilayah Daerah terhadap Belanja Modal sebesar 0,000 lebih kecil dari $\alpha=0,05$. Hasil penelitian ini memberikan kesimpulan bahwa, daerah dengan wilayah yang lebih luas, Belanja Modalnya akan cenderung lebih tinggi.

Hal ini karena wilayah yang lebih luas membutuhkan sarana dan prasarana yang lebih banyak, dan pembangunan infrastruktur yang lebih banyak harus dilakukan, sehingga belanja modal yang dianggarkan juga harus lebih besar. Hal ini berdasarkan interpretasi Undang-Undang Nomor 33 Tahun 2004. Luas kawasan merupakan salah satu variabel yang mencerminkan kebutuhan akan penyediaan sarana dan prasarana.

Hasil penelitian ini sejalan dengan temuan Kusnandar dan Siswantoro (2018) bahwa sebagian luas lahan berpengaruh positif terhadap anggaran belanja modal. Memiliki infrastruktur yang baik merupakan salah satu tujuan pembangunan daerah, yaitu dengan infrastruktur yang maksimal, pelaksanaan tugas pemerintahan dapat berjalan dengan lancar. Menurut penelitian Kusnandar dan Siswantoro (2017), dibandingkan dengan daerah yang kurang luas, daerah yang lebih luas membutuhkan lebih banyak sarana dan prasarana untuk memberikan pelayanan kepada masyarakat.

Daerah yang memiliki wilayah yang lebih luas, memiliki jumlah penduduk yang lebih banyak sehingga untuk mengimbangi kebutuhan masyarakat akan sarana dan prasarana serta mendukung berbagai produktivitas masyarakat di daerah tersebut harus disediakan infrastruktur yang memadai yang proporsional dengan jumlah penduduk. di daerah. Hasil penelitian ini juga 
sejalan dengan penelitian yang dilakukan oleh Ardhini (2016) dimana luas wilayah berpengaruh positif signifikan terhadap alokasi belanja modal.

Alokasi belanja modal yang dilakukan oleh daerah sangat dipengaruhi oleh besarnya daerah itu sendiri. Luas suatu wilayah dapat dijadikan tolak ukur suatu daerah untuk mengalokasikan anggarannya untuk pembangunan, terutama dalam bentuk pembangunan infrastruktur berupa jalan dan jaringan. Pembangunan infrastruktur berupa jalan raya akan memudahkan akses ke suatu daerah dan dapat memperlancar transportasi sehingga memperlancar arus barang dari satu daerah ke daerah lain. Kelancaran arus barang dapat menarik investor untuk berinvestasi. Dan ini bisa meningkatkan perekonomian daerah itu sendiri.

\section{KESIMPULAN DAN SARAN}

Berdasarkan hasil temuan penelitian dan pengujian hipotesis yang diajukan sebelumnya dapat disimpulkan bahwa :

1. Hasil penelitian ini membuktikan bahwa pertumbuhan ekonomi tidak berpengaruh signifikan terhadap belanja modal pemerintah daerah dengan nilai signifikansi sebesar 0,626 $>0,05$ dan nilai $\mathrm{t}_{\text {hitung }}<\mathrm{t}_{\text {tabel, }}$ yaitu $-0,490<1.993$ maka H1 ditolak.

2. Hasil penelitian ini didapatkan bahwa Pendapatan Asli Daerah berpengaruh terhadap belanja modal pemerintah daerah dengan nilai signifikansi sebesar $0,000<0,05$ dan nilai $\mathrm{t}_{\text {hitung }}<\mathrm{t}_{\text {tabel, }}$, yaitu $3.724>1.993$ maka $\mathrm{H} 2$ diterima.

3. Hasil penelitian ini membuktikan bahwa jumlah penduduk tidak berpengaruh terhadap belanja modal pemerintah daerah dengan nilai signifikansi sebesar $0,114>0,05$ dan nilai $\mathrm{t}_{\text {hitung }}<\mathrm{t}_{\text {table }}$ yaitu $1.598<1.993$ maka H3 ditolak sehingga dapat disimpulkan bahwa variable jumlah penduduk tidak berpengaruh terhadap belanja modal Pemerintah pada Pemerintah Daerah Kabupaten/Kota di Sumatera Barat Tahun 2016-2019.

4. Hasil penelitian ini didapatkan bahwa bahwa luas wilayah berpengaruh terhadap belanja modal pemerintah daerah dengan nilai signifikansi sebesar $0,000<0,05$ dan nilai $\mathrm{t}_{\text {hitung }}<\mathrm{t}$ tabel, yaitu $4.357>1.993$ maka $\mathrm{H} 4$ diterima.

Meskipun peneliti telah berusaha merancang dan mengembangkan penelitian sedemikian rupa, namun masih terdapat beberapa keterbatasan dalam penelitian ini yang masih perlu direvisi bagi penelitian selanjutnya yaitu, Peneliti hanya mengambil empat variabel independen sehingga penelitian ini belum dapat menjelaskan semua variabel yang mempengaruhi belanja modal. Hal ini dapat dilihat dari tingkat $\mathrm{R}$ square sebesar $65,6 \%$ dan sisanya dipengaruhi oleh variabel yang tidak diteliti dalam penelitian ini.

Dari kesimpulan yang telah diperoleh dari hasl penelitan ini, maka dapt diberikan beberapa saran sebagai berikut :

1. Banyaknya pemerintah daerah yang tidak mencantumkan belanja pemeliharaan secara lengkap setiap tahunnya sehingga penelitian selanjutnya perlu memperluas sampel agar hasil penelitian lebih akurat dan mencerminkan keadaan yang sebenarnya atau mengambil sampel dalam ruang lingkup yang lebih besar seperti pemerintah provinsi dimana belanja pemeliharaan lebih diperhatikan pada tingkatan pemerintahan yang lebih tinggi.

2. Peneliti berikutnya hendaknya mengambil sampel secara langsung melalui pemerintah daerah dengan mempertimbangkan karakteristik kualitatif laporan keuangan agar lebih relevan sehingga penelitian menjadi lebih baik.

3. Penelitian selanjutnya hendaknya menambahkan variabel lain diluar aspek keuangan yaitu aspek non keuangan seperti kebijakan pemerintah setempat, atau inflasi dan atau faktor potensial lainnya, atau dapat menambahkan lagi variabel aspek keuangan seperti Dana 
Alokasi Umum, Dana Alokasi Khusus, Dana Bagi Hasil dan lain-lain, agar penelitian menjadi lebih baik.

\section{DAFTAR PUSTAKA}

Abdul Halim Dan Syam Kusufi. (2016). Akuntansi Sektor Publik: Teori, Konsep Dan Aplikasi. Akuntansi Sektor Publik: Teori, Konsep Dan Aplikasi.

Adyatma, E., \& Oktaviani, R. M. (2015). Pengaruh Pendapatan Asli Daerah Dan Dana Alokasi Umum Terhadap Belanja Modal Dengan Pertumbuhan Ekonomi Sebagai Pemoderasi. Jurnal Dinamika Akuntansi, Keuangan Dan Perbankan.

Andirfa, M., Basri, H., \& Majid, M. S. A. (2016). Pengaruh Belanja Modal, Dana Perimbangan Dan Pendapatan Asli Daerah Terhadap Kinerja Keuangan Kabupaten Dan Kota Di Provinsi Aceh. Jurnal Magister Akuntansi.

Andriyani, I., \& Armereo, C. (2016). Pengaruh Suku Bunga, Inflasi, Nilai Buku Terhadap Harga Saham Perusahaan Indeks Lq45 Yang Terdaftar Di Bursa Efek Indonesia (Bei). Orasi Bisnis. Diambil Dari Https://Www.Jurnal.Polsri.Ac.Id/Index.Php/Admniaga/Article/View/633

Anugrawati, R. A., Aji, S., \& Farida, U. (2018). Analisis Pengaruh Customer Relationship Marketing Dan Service Quality Terhadap Loyalitas Nasabah Pt Bank Rakyat Indonesia (Persero), Tbk. Unit Mlarak Kantor Cabang Ponorogo. Isoquant: Jurnal Ekonomi, Manajemen Dan Akuntansi.

Arikunto. (2019). Metodelogi Penelitian, Suatu Pengantar Pendidikan. In Rineka Cipta, Jakarta (Hal. 21).

Asmuruf, F., Rumate, V. A., \& Kawung, G. M. V. (2015). Pengaruh Pendapatan Dan Jumlah Penduduk Terhadap Pendapatan Asli Daerah ( Pad) Di Kota Sorong. Jurnal Berkala Ilmu Efesien.

Astuti, I., \& Astika, I. (2016). Pengaruh Jumlah Penduduk, Dana Alokasi Umum, Dan Dana Alokasi Khusus Terhadap Kesejahteraan Masyarakat Kabupaten/Kota Di Provinsi Bali. EJurnal Akuntansi.

Boediono. (2017). Ekonomi Moneter. Seri Sinopsis Pengantar Ilmu Ekonomi No. 5.

Bungin, B. (2016). Penelitian Kualitatif: Komunikasi, Ekonomi, Kebijakan Publik, Dan Ilmu Sosial Lainnya. Kencana.

Dewi, G. (2017). Pengaruh Moralitas Individu Dan Pengendalian Internal Pada Kecurangan Akuntansi (Studi Eksperimen Pada Pemerintah Daerah Provinsi Bali). Jia (Jurnal Ilmiah Akuntansi). Diambil Dari Https://Ejournal.Undiksha.Ac.Id/Index.Php/Jia/Article/View/9984

Ghozali, I., \& Ratmono, D. (2017). Analisis Multivariat Dan Ekonometrika. Universitas Diponegoro.

Giovanni, G. (2019). ... Biaya Agensi Dalam Memediasi Hubungan Antara Karakteristik Dewan Komisaris Terhadap Nilai Perusahaan Dengan Pendekatan Teori Keagenan (Studi Kasus Pada .... Eprints.Kwikkiangie.Ac.Id. Diambil Dari Http://Eprints.Kwikkiangie.Ac.Id/180/

Gunantara, P. C., \& Dwirandra, A. A. N. . (2014). Pengaruh Pendapatan Asli Daerah Dan Dana Alokasi Umum Pada Pertumbuhan Ekonomi Dengan Belanja Modal Sebagai Variabel Pemoderasi Di Bali. Akuntansi Universitas Udayana.

Hairiyah, H., Malisan, L., \& Fakhroni, Z. (2018). Pengaruh Dana Alokasi Umum Dau Dana Alokasi Khusus Dak Dan Pendapatan Asli Daerah Pad Terhadap Belanja Modal. Kinerja. 
Imam, S., \& Irwanto, A. (2015). Peran Transfer Dana Penyesuaian Dan Dana Perimbangan Terhadap Peningkatan Belanja Modal Daerah Untuk Menciptakan Quality Spending. Simposium Nasional Akuntansi 18.

Jaya, J. D., \& Sisdyani, E. A. (2014). Pengaruh Pendapatan Asli Daerah, Dana Alokasi Umum Pendapatan. E-Jurnal Ep.

Jefri, R. (2018). Teori Stewardship Dan Good Governance. Economics Bosowa. Diambil Dari Http://Economicsbosowa.Unibos.Id/Index.Php/Eb/Article/View/162

Kosim, E. (2017). Pengaruh Pendapatan Asli Daerah (Pad), Dana Alokasi Umum (Dau) Dan Sisa Lebih Pembiayaan Anggaran (Silpa) Terhadap Anggaran Belanja Modal Pada Pemerintah Kota Banjar. Journal Of Management Review.

Kusnandar, \& Siswantoro, D. (2012). Pengaruh Dana Alokasi Umum, Pendapatan Asli Daerah, Sisa Lebih Pembiayaan Anggaran Dan Luas Wilayah Terhadap Belanja Modal. Sna Xv Banjarmasin.

M.L. Jhingan. (2007). Ekonomi Pembangunan Dan Perencanaan. Rajawali Press.

Mahendra, A. (2016). Analisis Pengaruh Pertumbuhan Ekonomi, Pendapatan Perkapita, Inflasi Dan Pengangguran Terhadap Jumlah Penduduk Miskin Di Provinsi Sumatera Utara. Jurnal Riset Akuntansi Dan Keuangan.

Mahendra Putra, P., \& Ulupui, I. (2015). Pendapatan Asli Daerah, Dana Alokasi Umum, Dana Alokasi Khusus, Untuk Meningkatkan Indeks Pembangunan Manusia. E-Jurnal Akuntansi.

Mahmudi, M. (2003). New Public Management (Npm): Pendekatan Baru Manajemen Sektor Publik. Sinergi.

Meiriasari, V. (2017). Pengaruh Corporate Governance, Kepemilikan Keluarga, Kepemilikan Institusional Dan Ukuran Perusahaan (Firm Size) Terhadap Biaya Utang. Jurnal Ilmiah Ekonomi Global Masa Kini. Diambil Dari Http://Ejournal.Uigm.Ac.Id/Index.Php/Egmk/Article/View/233

Muhtarom, A. (2015). Analisis Pad (Pendapatan Asli Daerah) Terhadap Kesejahteraan Masyarakat Kabupaten Lamongan Periode Tahun 2010-2015. Jurnal Ekbis.

Mulyani, S. (2017). Pengaruh Belanja Modal, Ukuran Pemerintah Daerah, Intergovernmentalrevenue Dan Pendapatan Asli Daerah Terhadap Kinerja Keuangan. Repository.Ump.Ac.Id. Diambil Dari Http://Repository.Ump.Ac.Id/Id/Eprint/1566

Novianto, R., \& Hanafiah, R. (2015). Pengaruh Pendapatan Asli Daerah, Dana Perimbangan Dan Kinerja Keuangan Terhadap Alokasi Belanja Modal Pada Pemerintah Kabupaten / Kota Di Provinsi Kalimatan Barat. Jurnal Ekonomi.

Nurhayati, N. (2015). Pengaruh Intensifikasi Dan Ekstensifikasi Pajak Dan Retribusi Daerah Terhadap Peningkatan Pendapatan Asli Daerah Dengan Dimoderasi Pelaksanaan Good Governance Pada Kabupaten / Kota Di Wilayah Iii Cirebon. Jurnal Riset Keuangan Dan Akuntansi.

Pendapatan, P., Daerah, A., Dana, D. A. N., Studi, D., Kabupaten, P., Kota, D. A. N., \& Aceh, D. I. (2013). Alokasi Umum Terhadap Belanja Modal Serta Dampaknya Terhadap Pertumbuhan Ekonomi. Mawarni.

Perdana. (2018). Anggaran Pendapatan Dan Belanja Daerah. Journal Of Chemical Information And Modeling.

Priambudi, W. (2017). Pengaruh Pendapatan Asli Daerah Dan Dana Alokasi Umum Terhadap Belanja Modal Pada Kabupaten Dan Kota Di Pulau Jawa Tahun 2013. Nominal, Barometer Riset Akuntansi Dan Manajemen. 
Riduansyah, M. (2003). Kontribusi Pajak Daerah Dan Retribusi Daerah Terhadap Pendapatan Asli Daerah (Pad) Dan Anggaran Pendapatan Dan Belanja Daerah (Apbd) Guna Mendukung Pelaksanaan Otonomi Daerah (Studi Kasus Pemerintah Daerah Kota Bogor). Makara Human Behavior Studies In Asia.

Saputra, B., \& Mahmudi. (2015). Pengaruh Desentralisasi Fiskal Terhadap Pertumbuhan Ekonomi Dan Kesejahteraan Masyarakat. Jurnal Akuntansi Dan Auditing Indonesia.

Sari, P., \& Ningsih, N. H. (2019). Pengaruh Jumlah Penduduk Terhadap Belanja Modal Melalui Pad, Dau, Dan Dak Sebagai Variabel Intervening. Akuntabilitas: Jurnal Penelitian Dan Pengembangan Akuntansi, 12(2), 99-112.

Simmamora. (2012). Uji Validitas Dan Reabilitas Metode Penlitian. Mercubuana.

Sugiono, A. (2001). Metode Penelitian Pendidikan Pendekatan Kuantitatif. Kualitatif Dan R\&D.

Suryana. (2012). Metodologi Penelitian: Metodologi Penelitian Model Prakatis Penelitian Kuantitatif Dan Kualitatif. Universitas Pendidikan Indonesia.

Wahyuni, A. S. (2019). Kritik Teori Keagenan Dalam Artikel Akuntansi: Konteks Ke-IndonesiaAn. Akuntansi Dan Teknologi Informasi. Diambil Dari Http://Www.Journal.Ubaya.Ac.Id/Index.Php/Jati/Article/View/2463

Widhiari, N., \& Aryani Merkusiwati, N. (2015). Pengaruh Rasio Likuiditas, Leverage, Operating Capacity, Dan Sales Growth Terhadap Financial Distress. E-Jurnal Akuntansi.

Yulianti, D. (2018). Kemitraan Dalam Corporate Social Responsibility (Csr) Melalui Pemberdayaan Masyarakat Untuk Mewujudkan Pembangunan .... 